\title{
Influence of arbuscular mycorrhizal fungi on the vegetative development of citrus rootstocks ${ }^{1}$
}

\author{
Marina Martinello Back², Taís Altmann², Paulo Vitor Dutra de Souza²
}

\section{ABSTRACT}

The use of arbuscular mycorrhizal fungi (AMF) in the production of rootstocks is an alternative to accelerate plant growth. However, their response depends on the symbionts species and environment. This study aimed at evaluating the influence of AMF species [Scutelospora heterogama, Gigaspora margarita, Glomus etunicatum, Acaulospora sp. and a control (non-inoculated)] on the vegetative development of citrus rootstocks \{citrange 'Fepagro C37 Reck' [P. trifoliata (L.) Raf. x C. sinensis (L.) Osbeck.] and 'Kumquat' [Fortunella hindsii (L.) Swingle]\}. The experimental design consisted of split-plot randomized blocks, with 10 plants per plot and 3 replications. Height, stem diameter, number of leaves, leaf area and fresh and dry root and shoot mass were evaluated. The colonization of AMF in the roots was also assessed, determining the percentage of colonization and density of hyphae, arbuscules and vesicles. The rootstocks showed no difference for the plant growth parameters, in the absence of AMF. The AMF species colonized the rootstocks roots, but were only effective in accelerating the citrange 'Fepagro C37 Reck' growth, especially when inoculated with Scutelospora heterogama, Gigaspora margarita and Glomus etunicatum. The influence of AMF on vegetative development depends on the citrus rootstock species.

KEYWORDS: Endomycorrhizae; Fepagro C37 Reck; Fortunella; seedlings production.

\section{INTRODUCTION}

The Brazilian citriculture is one of the most competitive activities in international agribusiness. However, in some States, such as Rio Grande do Sul, the seedling production exhibits numerous limitations. One of them is the lack of rootstock diversification in the orchards, where they are grafted onto Poncirus trifoliata (L.) Raf. Thus, studies with different varieties of rootstock are needed, in order to decrease the vulnerability of the sector to possible

\section{RESUMO}

Influência de fungos micorrízicos arbusculares no desenvolvimento vegetativo de porta-enxertos de citros

A utilização de fungos micorrízicos arbusculares (FMA) na produção de porta-enxertos é uma alternativa para acelerar o desenvolvimento de plantas. Entretanto, sua resposta depende da espécie dos simbiontes e do ambiente. Objetivou-se avaliar a influência de espécies de FMA[Scutelospora heterogama, Gigaspora margarita, Glomus etunicatum, Acaulospora sp. e testemunha (não-inoculada)] no desenvolvimento vegetativo de porta-enxertos de citros \{citrangeiro 'Fepagro C37 Reck' [P. trifoliata (L.) Raf. x C. sinensis (L.) Osbeck.] e 'Kumquateiro' [Fortunella hindsii (L.) Swingle]\}. O delineamento experimental foi de blocos ao acaso, em parcelas subdivididas, com 10 plantas por parcela e 3 repetições. Avaliaram-se a altura, diâmetro do caule, número de folhas, área foliar e a massa fresca e seca da raiz e da parte aérea. Também foi avaliada a colonização das micorrizas arbusculares nas raízes, determinando-se a porcentagem de colonização e a densidade de hifas, arbúsculos e vesículas. Entre os porta-enxertos, não houve diferença nos parâmetros de desenvolvimento vegetativo, na ausência dos FMA. As espécies de FMA colonizaram as raízes dos porta-enxertos, mas somente foram eficientes em acelerar o crescimento do citrangeiro 'Fepagro C37 Reck', com destaque para Scutelospora heterogama, Gigaspora margarita e Glomus etunicatum. A influência de FMA no desenvolvimento vegetativo depende da espécie de porta-enxerto de citros.

PALAVRAS-CHAVE: Endomicorriza; Fepagro C37 Reck; Fortunella; produção de mudas.

new diseases (Souza et al. 2010). Moreover, the seedlings produced must be genetically healthy, in order to provide a high-quality product to citrus growers (Koller 2013).

The Fortunella genus is widely used in landscaping, not only because of its beautiful canopy, flowers and fruits, but also for its low vigor (Mazzini \& Pio 2010), which gives this species the potential for being an alternative rootstock of citrus trees. Smaller canopies allow denser orchards, with greater production per cubic meter. Furthermore, Fortunella trees are

1. Manuscript received in Jul./2016 and accepted for publication in Dec./2016 (http://dx.doi.org/10.1590/1983-40632016v4642180).

2. Universidade Federal do Rio Grande do Sul, Faculdade de Agronomia, Departamento de Horticultura e Silvicultura, Porto Alegre, RS, Brazil.E-mails: backmarina@gmail.com, taisaltmann91@hotmail.com, pvdsouza@ufrgs.br. 
highly resistant to citrus canker and tolerant to citrus variegated chlorosis, which is a very important disease in the Brazilian citriculture (Koller 2013).

A rootstock with significant potential, that has been successfully used in several orchards in the Rio Grande do Sul State, is the citrange 'Fepagro C37 Reck' [P. trifoliata (L.) Raf. x C. sinensis (L.) Osbeck.]. It is a 'trifoliata' hybrid that exhibits desirable characteristics, in addition to rapid growth under greenhouse conditions (Oliveira et al. 2010, Koller 2013).

Greenhouse cultivation practices include the use of arbuscular mycorrhizal fungi (AMF) as an alternative to optimize citrus seedlings by reducing the seedling formation time (Johnson \& Graham 2013), what is important for greenhouse owners, since the grafting stage is reached sooner, decreasing costs and providing seedlings to the market in a shorter amount of time. The AMF inoculation may enable seedlings to be produced within 18 to 22 months, as recommended by the Brazilian Ministry of Agriculture, Livestock and Supply (Brasil 2005). This timeframe is sometimes impossible to reach in the South of Brazil, due to the slower plant growth caused by low fall/winter temperatures.

The use of AMF also allows the production of more vigorous and uniform rootstocks, with a high survival index and better initial performance on the field (Nunes et al. 2008). AMF are mutualistically associated with plants, resulting in improvements to their nutritional status and a decline in biotic (pests and diseases) or abiotic (nutritional imbalance and water deficit) stress losses.

Symbiosis occurs when a plant supplies the fungus with energy for growth and maintenance via photosynthetic products, while the fungus provides nutrients and water to the plant (Wu et. al. 2011a, Ortas 2012, Jayme \& Quigley 2014). The structures responsible for this exchange are called arbuscules, which are vesicles, globous structures, that accumulate glycogen and lipids. These structures are reserves of AMF formed during periods of low temperature, when low fungal and host activities occur (Smith \& Smith 2011).

However, it is important to point out that the symbiosis between the plant and AMF is influenced by both the citrus rootstock species/cultivar and the AMF species (Smith \& Smith 2011). Thus, this study aimed at assessing the influence of AMF species on the vegetative development of citrus rootstocks.

\section{MATERIAL AND METHODS}

The study was divided into two phases, both carried out at the Universidade Federal do Rio Grande do Sul (UFRGS), Rio Grande do Sul State, Brazil. The first one took place in Porto Alegre $\left(30^{\circ} 29^{\prime} \mathrm{S}\right.$ and $51^{\circ} 06^{\prime} \mathrm{W}$ ), in February 2013, with the colonization and inoculation of AMF in a greenhouse. The second one was carried out in in Eldorado do Sul $\left(30^{\circ} 05^{\prime} 22^{\prime \prime} \mathrm{S}\right.$ and $\left.51^{\circ} 39^{\prime} 08^{\prime \prime} \mathrm{W}\right)$, in June 2013, after plant transplantation.

Two rootstocks \{citrange 'Fepagro C37 Reck' [P. trifoliata (L.) Raf. x C. sinensis (L.) Osbeck.] and 'Kumquat tree' [Fortunella hindsii (L.) Swingle]\} inoculated with AMF species (Scutelospora heterogama, Gigaspora margarita, Glomus etunicatum and Acaulospora sp.), as well as a non-inoculated control, were used.

A complete randomized split-plot blocks design, in a 5 x 2 factorial scheme, was adopted, where plots consisted of AMF treatments (four species and one control) and subplots of two rootstocks, with three replications and 10 plants per plot.

The rootstock seeds used were extracted from mature fruits collected from mother plants cultivated in the citrus collection of the UFRGS, as described by Souza \& Schäfer (2006). The seeds were subjected to a thermal treatment (immersion for $10 \mathrm{~min}$ in water, at $52{ }^{\circ} \mathrm{C}$ ).

The AMF inoculum used in the experiment was reproduced in laboratory and the inoculation for each AMF species was performed during the colonization of rootstocks in Carolina Soil ${ }^{\circledR}$ commercial substrate (peat, carbonized rice husks and vermiculite), in plastic trays ( $60 \mathrm{~cm}$ long x $40 \mathrm{~cm}$ wide x $10 \mathrm{~cm}$ high). The substrate was previously autoclaved at $120^{\circ} \mathrm{C}$ ( $1 \mathrm{~atm})$, for $1 \mathrm{~h}$, and the process was repeated three times, at 24-h intervals.

The trays were placed on a concrete bench, in a protected environment covered by an anti-aphid insect screen. Each tray contained one of the treatments with AMF (control and four AMF species), divided into two equal parts for each rootstock variety.

The trays with the AMF inoculum were half filled with substrate, which was added with a $400 \mathrm{~g}$ layer of inoculum (approximately $2 \mathrm{~mm}$ ), and completely filled with more substrate. A total of 50 seeds from each rootstock were colonized per treatment. Irrigation was conducted using a watering can, adding $1 \mathrm{~L}$ of water per tray every two days. 
The second phase of the experiment began in June 2013, when the seedlings reached a height of $10 \mathrm{~cm}$ (150 days after colonization). The plants were transplanted to black polyethylene bags $(5 \mathrm{~L})$ filled with Vida ${ }^{\circledR}$ commercial substrate, composed of eucalyptus bark previously disinfested with a $7 \%$ solution of formaldehyde. The rootstocks were kept on benches, in a greenhouse, and submitted to drip irrigation for $5 \mathrm{~min}$, twice a day, totaling $50 \mathrm{~mL}$ of water per day. Fertilization took place every 60 days, with $5 \mathrm{~g} \mathrm{~L}^{-1}$ of Kristalon Laranja ${ }^{\circledR}(6-12-36)$, in a volume of $50 \mathrm{~mL}^{\text {plant }}{ }^{-1}$.

After 240 days in the greenhouse (March 2014), plant height $(\mathrm{cm})$ was measured from the base of the stem to the apex, stem diameter $(\mathrm{mm})$ with a digital caliper, and the number of leaves was counted. The leaf area $\left(\mathrm{cm}^{2}\right)$ per plant was determined with a LI-Meter leaf area meter. Fresh root and shoot biomass (g) were also evaluated. After samples were oven dried at $65^{\circ} \mathrm{C}$, until reaching a constant mass, the root and shoot dry biomass $(\mathrm{g})$ were measured.

To assess the AMF colonization, two segments of secondary roots were collected per plant from the 10 plants of each treatment. The roots were washed with distilled water, fractionated at $1 \mathrm{~cm}$ long and stored in FAA (formaldehyde, alcohol and acetone) medium, for fixation and conservation. Then, 15 root segments per treatment were randomly collected, clarified and stained with a trypan blue solution (Phillips \& Hayman 1970). After the staining process, the root segments were mounted onto glass slides and examined under microscope to assess the presence and intensity of hyphae, arbuscules and vesicles. A 40x amplification under optical microscope was used to obtain the number of infected segments, in relation to the total analyzed. To determine the hyphal density, a value of 0 was attributed to the absence of structures, 1 for low presence, 2 for average presence and 3 for high presence. At 100x amplification, vesicle and arbuscle densities were related to a scale of 0 to 3 , where 0 was attributed to the absence of structures, 1 for 1-50 structures, 2 for 51-100 and 3 for more than 100 (Nemec 1992). The entire process was repeated three times per treatment.

The results were submitted to analysis of variance and the treatments compared using the Tukey's test at $5 \%$.

\section{RESULTS AND DISCUSSION}

No significant difference in vegetative development was observed between the rootstocks tested without AMF inoculation (Tables 1 and 2). However, in the presence of AMF, the 'Fepagro C37 Reck' exhibited much better vegetative development than that of the kumquat tree, particularly in terms of height $(\mathrm{cm})$, stem diameter $(\mathrm{mm})$, leaf area $\left(\mathrm{cm}^{2}\right.$ plant $\left.{ }^{-1}\right)$ and root and shoot dry mass $\left(\mathrm{g} \mathrm{plant}^{-1}\right)$. These results reinforce the significant dependence of the citrange 'Fepagro C37 Reck' on the presence of AMF for its vegetative development. This strong dependence is attributed to the fact that this genotype is descendant from the sweet orange tree [Citrus sinensis (L.) Osbeck], a citrus species with a root system that exhibits underdeveloped absorbent hairs, hindering water and nutrient absorption ( $\mathrm{Wu}$ et al. 2011b, Ortas 2012, Zambrosi et al. 2012).

This was not observed for the kumquat tree rootstock, since the use of mycorrhizae had no effect on its vegetative development, likely due to the genetics of the host and/or its interaction with the AMF species. Li et al. (2013) found that

Table 1. Plant height, stem diameter, leaf area and number of leaves of rootstocks from citrus trees submitted or not to arbuscular mycorrhizal fungi (AMF) species.

\begin{tabular}{|c|c|c|c|c|c|c|c|c|}
\hline \multirow{3}{*}{ AMF } & \multicolumn{8}{|c|}{ Rootstock } \\
\hline & $\begin{array}{c}\text { Fepagro C37 } \\
\text { Reck }\end{array}$ & $\begin{array}{c}\text { Kumquat } \\
\text { tree }\end{array}$ & $\begin{array}{c}\text { Fepagro C37 } \\
\text { Reck }\end{array}$ & $\begin{array}{c}\text { Kumquat } \\
\text { tree }\end{array}$ & $\begin{array}{c}\text { Fepagro C37 } \\
\text { Reck }\end{array}$ & $\begin{array}{c}\text { Kumquat } \\
\text { tree }\end{array}$ & $\begin{array}{c}\text { Fepagro C37 } \\
\text { Reck }\end{array}$ & $\begin{array}{c}\text { Kumquat } \\
\text { tree }\end{array}$ \\
\hline & \multicolumn{2}{|c|}{ Plant height $(\mathrm{cm})$} & \multicolumn{2}{|c|}{ Stem diameter $(\mathrm{mm})$} & \multicolumn{2}{|c|}{ Leaf area $\left(\mathrm{cm}^{2}\right.$ plant $\left.^{-1}\right)$} & \multicolumn{2}{|c|}{ Number of leaves plant ${ }^{-1}$} \\
\hline Control & $17.56 \mathrm{aB}$ & $16.54 \mathrm{aA}$ & $2.50 \mathrm{aB}$ & $2.58 \mathrm{aA}$ & $60.54 \mathrm{aB}$ & $38.30 \mathrm{aA}$ & $14.09 \mathrm{aB}$ & $19.10 \mathrm{aA}$ \\
\hline Scutelospora heterogama & $50.71 \mathrm{aA}$ & $15.30 \mathrm{bA}$ & $4.61 \mathrm{aA}$ & $2.45 \mathrm{bA}$ & $195.84 \mathrm{aA}$ & $29.63 \mathrm{bA}$ & $27.76 \mathrm{aA}$ & $16.93 \mathrm{bA}$ \\
\hline Gigaspora margarita & $53.54 \mathrm{aA}$ & $18.21 \mathrm{bA}$ & $4.72 \mathrm{aA}$ & $2.77 \mathrm{bA}$ & $185.21 \mathrm{aA}$ & $38.63 \mathrm{bA}$ & $25.16 \mathrm{aA}$ & $17.58 \mathrm{bA}$ \\
\hline Glomus etunicatum & $47.52 \mathrm{aA}$ & $18.08 \mathrm{bA}$ & $4.83 \mathrm{aA}$ & $2.79 \mathrm{bA}$ & $180.98 \mathrm{aA}$ & $39.05 \mathrm{bA}$ & $25.47 \mathrm{aA}$ & $19.38 \mathrm{bA}$ \\
\hline Acaulospora sp. & $35.92 \mathrm{aAB}$ & $18.75 \mathrm{bA}$ & $4.57 \mathrm{aA}$ & $2.92 \mathrm{bA}$ & $151.74 \mathrm{aAB}$ & $39.50 \mathrm{bA}$ & $24.02 \mathrm{aA}$ & $19.13 \mathrm{aA}$ \\
\hline $\mathrm{CV}(\%)$ & \multicolumn{2}{|c|}{19.4} & \multicolumn{2}{|c|}{4.88} & \multicolumn{2}{|c|}{12.15} & \multicolumn{2}{|c|}{10.56} \\
\hline
\end{tabular}

Different lower case letters in the columns and upper case letters in the rows indicate a significant difference in rootstocks and AMF, respectively, based on the Tukey's test $(\mathrm{p}<0.05)$. 
arbuscular mycorrhizal fungi from the Diversispora spurca species had a positive influence on growth, root system architecture and chlorophyll content of the kumquat tree (Fortunella margarita). Thus, the kumquat tree may respond to mycorrhization, but the AMF species is important for its positive effect.

With respect to individual analysis of AMF in the citrange 'Fepagro C37 Reck', only the Acaulospora sp. species showed no difference for plant height, leaf area or root fresh mass, if compared to the control. On the other hand, the inoculation of the Glomus etunicatum, Gigaspora margarita and Scutelospora heterogama species showed potential for this rootstock.

Regarding the AMF colonization in the rootstock roots, colonization and the presence of fungal structures were observed in the two rootstock species assessed, with interaction between rootstock and AMF species (Table 3).
There was $100 \%$ colonization in both rootstocks submitted to AMF inoculation (Table 3 ), as well as a slight contamination in the control plants of the two rootstocks. This is likely due to the presence of insects in the experiment, such as ants, which may have transmitted spores to these plants. However, this type of contamination has been reported in other studies (Silveira et al. 2006, Nunes et al. 2008), without interfering in the results, since it was considered very low and, therefore, acceptable.

The AMF hyphae were present in the roots of the two rootstock species. However, for the citrange 'Fepagro C37 Reck', where inoculation had a beneficial effect, hyphal density was higher than in the kumquat tree. The citrange 'Fepagro C37 Reck' roots exhibited medium to high hyphal density (Figure 1B). On the other hand, there was a low density in kumquat tree roots (Figure 1A). Among

Table 2. Root and shoot fresh and dry mass of rootstocks from citrus trees submitted or not to inoculation with arbuscular mycorrhizal fungi (AMF) species.

\begin{tabular}{|c|c|c|c|c|c|c|c|c|}
\hline \multirow{4}{*}{$\mathrm{AMF}$} & \multicolumn{8}{|c|}{ Rootstock } \\
\hline & $\begin{array}{c}\text { Fepagro C37 } \\
\text { Reck }\end{array}$ & $\begin{array}{c}\text { Kumquat } \\
\text { tree }\end{array}$ & $\begin{array}{c}\text { Fepagro C37 } \\
\text { Reck }\end{array}$ & $\begin{array}{c}\text { Kumquat } \\
\text { tree }\end{array}$ & $\begin{array}{c}\text { Fepagro C37 } \\
\text { Reck }\end{array}$ & $\begin{array}{c}\text { Kumquat } \\
\text { tree }\end{array}$ & $\begin{array}{c}\text { Fepagro C37 } \\
\text { Reck }\end{array}$ & $\begin{array}{c}\text { Kumquat } \\
\text { tree }\end{array}$ \\
\hline & \multicolumn{2}{|c|}{ Root fresh mass } & \multicolumn{2}{|c|}{ Shoot fresh mass } & \multicolumn{2}{|c|}{ Root dry mass } & \multicolumn{2}{|c|}{ Shoot dry mass } \\
\hline & \multicolumn{8}{|c|}{$\longrightarrow$ g plant $^{-1}$} \\
\hline Control & $2.39 \mathrm{aB}$ & $1.88 \mathrm{aA}$ & $2.57 \mathrm{aB}$ & $1.49 \mathrm{aA}$ & $0.84 \mathrm{aB}$ & $0.58 \mathrm{aA}$ & $0.77 \mathrm{aB}$ & $0.50 \mathrm{aA}$ \\
\hline Scutelospora heterogama & $10.55 \mathrm{aA}$ & $1.52 \mathrm{bA}$ & $9.03 \mathrm{aA}$ & $1.08 \mathrm{bA}$ & $3.65 \mathrm{aA}$ & $0.45 \mathrm{bA}$ & $3.38 \mathrm{aA}$ & $0.36 \mathrm{bA}$ \\
\hline Gigaspora margarita & $9.92 \mathrm{aA}$ & $1.98 \mathrm{bA}$ & $8.31 \mathrm{aA}$ & $1.47 \mathrm{bA}$ & $3.87 \mathrm{aA}$ & $0.60 \mathrm{bA}$ & $4.18 \mathrm{aA}$ & $0.48 \mathrm{bA}$ \\
\hline Glomus etunicatum & $8.37 \mathrm{aA}$ & $1.76 \mathrm{bA}$ & $8.55 \mathrm{aA}$ & $1.45 \mathrm{bA}$ & $3.45 \mathrm{aA}$ & $0.60 \mathrm{bA}$ & $3.34 \mathrm{aA}$ & $0.52 \mathrm{bA}$ \\
\hline Acaulospora sp. & $7.43 \mathrm{aAB}$ & $1.88 \mathrm{bA}$ & $7.51 \mathrm{aA}$ & $1.86 \mathrm{bA}$ & $3.01 \mathrm{aA}$ & $0.66 \mathrm{bA}$ & $2.88 \mathrm{aA}$ & $0.53 \mathrm{bA}$ \\
\hline$\overline{\mathrm{CV}(\%)}$ & \multicolumn{2}{|c|}{10.92} & \multicolumn{2}{|c|}{11.04} & \multicolumn{2}{|c|}{18.55} & \multicolumn{2}{|c|}{12.38} \\
\hline
\end{tabular}

Table 3. Colonization, hyphal density and arbuscule and vesicle quantification in root segments from citrus tree rootstocks submitted or not to the inoculation with arbuscular mycorrhizal fungi (AMF) species.

\begin{tabular}{|c|c|c|c|c|c|c|c|c|}
\hline \multirow{3}{*}{ AMF } & \multicolumn{8}{|c|}{ Rootstock } \\
\hline & $\begin{array}{c}\text { Fepagro C37 } \\
\text { Reck }\end{array}$ & $\begin{array}{c}\text { Kumquat } \\
\text { tree }\end{array}$ & $\begin{array}{c}\text { Fepagro C37 } \\
\text { Reck }\end{array}$ & $\begin{array}{c}\text { Kumquat } \\
\text { tree }\end{array}$ & $\begin{array}{c}\text { Fepagro C37 } \\
\text { Reck }\end{array}$ & $\begin{array}{c}\text { Kumquat } \\
\text { tree }\end{array}$ & $\begin{array}{c}\text { Fepagro C37 } \\
\text { Reck }\end{array}$ & $\begin{array}{c}\text { Kumquat } \\
\text { tree }\end{array}$ \\
\hline & \multicolumn{2}{|c|}{ Colonization (\%) } & \multicolumn{2}{|c|}{ Hiphae } & \multicolumn{2}{|c|}{ Arbuscules } & \multicolumn{2}{|c|}{ Vesicles } \\
\hline Control & $9.78 \mathrm{aB}$ & $8.17 \mathrm{aB}$ & $0.31 \mathrm{aC}$ & $0.31 \mathrm{aB}$ & $0.31 \mathrm{aC}$ & $0.31 \mathrm{aB}$ & $0.12 \mathrm{aB}$ & $0.00 \mathrm{aA}$ \\
\hline Scutelospora heterogama & $100.00 \mathrm{aA}$ & $100.00 \mathrm{aA}$ & $1.62 \mathrm{aB}$ & $1.40 \mathrm{aA}$ & $1.62 \mathrm{aB}$ & $0.31 \mathrm{aB}$ & $0.04 \mathrm{aB}$ & $0.00 \mathrm{aA}$ \\
\hline Gigaspora margarita & $100.00 \mathrm{aA}$ & $100.00 \mathrm{aA}$ & $2.02 \mathrm{aAB}$ & $1.12 \mathrm{bA}$ & $2.02 \mathrm{aAB}$ & $1.12 \mathrm{bA}$ & $0.50 \mathrm{aA}$ & $0.19 \mathrm{bA}$ \\
\hline Glomus etunicatum & $100.00 \mathrm{aA}$ & $100.00 \mathrm{aA}$ & $2.23 \mathrm{aA}$ & $1.29 \mathrm{bA}$ & $2.23 \mathrm{aA}$ & $1.29 \mathrm{bA}$ & $0.58 \mathrm{aA}$ & $0.10 \mathrm{bA}$ \\
\hline Acaulospora sp. & $100.00 \mathrm{aA}$ & $100.00 \mathrm{aA}$ & $2.17 \mathrm{aAB}$ & $1.02 \mathrm{bA}$ & $2.17 \mathrm{aAB}$ & $1.02 \mathrm{bA}$ & $0.17 \mathrm{aB}$ & $0.06 \mathrm{aA}$ \\
\hline$\overline{\mathrm{CV}(\%)}$ & \multicolumn{2}{|c|}{2.66} & \multicolumn{2}{|c|}{16.06} & \multicolumn{2}{|c|}{16.06} & \multicolumn{2}{|c|}{11.16} \\
\hline
\end{tabular}




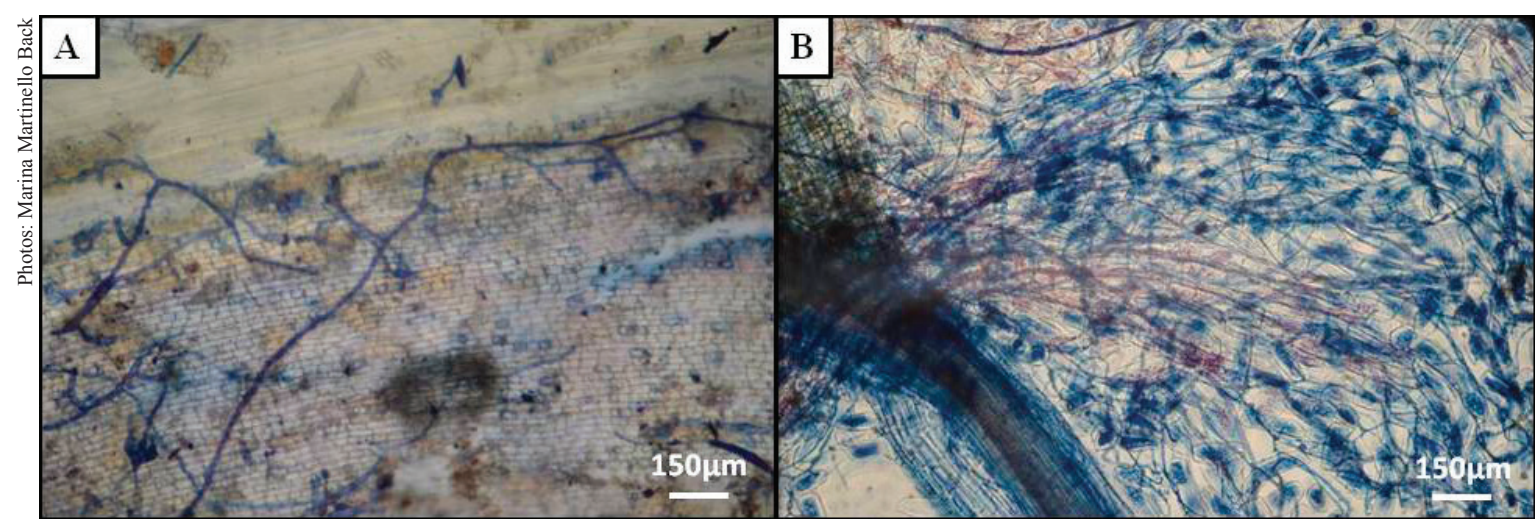

Figure 1. Rootstock roots of citrus trees inoculated with arbuscular mycorrhizal fungi. A - low hyphal density of Acaulosposa sp. in kumquat tree roots; B - high hyphal density of Scutelospora heterogama in citrange 'Fepagro C37 Reck' roots.

AMF species, there was no difference for hyphal density in kumquat roots. However, a different hyphal density was observed between AMF species in the citrange 'Fepagro C37 Reck' roots, highlighting the Glomus etunicatum species, which obtained a higher density (Table 3).

A high presence of arbuscules was observed in the citrange 'Fepagro C37 Reck' roots (Table 3 ), characterizing a greater symbiotic activity between fungus and plant, which explains the higher vegetative development of this rootstock.

There was a low presence of vesicles in the rootstocks roots tested, regardless of the AMF species. This occurred because the roots were collected in March, at the end of the summer, when the AMF did not need to accumulate reserves yet. Normally, under conditions for southern Brazil, these structures are formed starting in April and May (with lower temperatures and reduced photoperiod), in order to provide reserves to the AMF during the winter. Similar results were reported by Nunes et al. (2008 and 2013).

\section{CONCLUSIONS}

1. The influence of arbuscular mycorrhizal fungi (AMF) in vegetative development depends on the citrus tree rootstock;

2. The citrange 'Fepagro C37 Reck' is significantly dependent on the presence of AMF in its roots, particularly the Glomus etunicatum, Gigaspora margarita and Scutelospora heterogama species;

3. AMF colonize the roots of the kumquat tree [Fortunella hindsii (L.) Swingle], however, they have no effect on its vegetative development.

\section{REFERENCES}

BRASIL. Ministério da Agricultura, Pecuária e Abastecimento. Instrução Normativa $n^{\circ} 24$ de 16 de dezembro de 2005. Normas para produção, comercialização e utilização de mudas. Diário Oficial da União, Brasília, DF, n. 243, 20 dez. 2005. Seção 1.

JAYME, B.; QUIGLEY, M. Influence of arbuscular mycorrhiza on growth and reproductive response of plants under water deficit: a meta-analysis. Mycorrhiza, v. 24, n. 2, p. 109-119, 2014.

JOHNSON, N. C.; GRAHAM, J. H. The continuum concept remains a useful framework for studying mycorrhizal functioning. Plant and Soil, v. 363, n. 1, p. 411-419, 2013.

KOLLER, O. L. (Org.). Citricultura catarinense. Florianópolis: Epagri, 2013.

LI, Y.; ZOU, Y. N.; WU, Q. S. Effects of Diversispora spurca inoculation on growth, root system architecture and chlorophyll contents of four citrus genotypes. International Journal of Agriculture \& Biology, v. 15, n. 2, p. 342-346, 2013.

MAZZINI, R. B.; PIO, R. M. Caracterização morfológica de seis variedades cítricas com potencial ornamental. Revista Brasileira de Fruticultura, v. 32, n. 2, p. 463470, 2010.

NEMEC, S. Glomus intraradix effects on citrus rootstock seedling growth in various potting media. Journal of Agricultural Science, v. 118, n. 1, p. 315-323, 1992.

NUNES, J. L. S. et al. Desenvolvimento de plântulas de pessegueiro 'Okinawa' inoculadas com micorrizas arbusculares isoladas de pomares de pessegueiros e de vinhedos. Revista Brasileira de Fruticultura, v. 35, n. 3, p. 845-852, 2013. 
NUNES, J. L. S. et al. Incremento no desenvolvimento vegetativo do porta-enxerto de pessegueiro 'Aldrighi' por fungos micorrízicos arbusculares autóctones. Ciência e Agrotecnologia, v. 32, n. 6, p. 1787-1793, 2008.

OLIVEIRA, R. P. et al. Porta-enxertos para citros. In: EMPRESA BRASILEIRA DE PESQUISA AGROPECUÁRIA (Embrapa). Produção orgânica de citros no Rio Grande do Sul. Pelotas: Embrapa Clima Temperado, 2010. p. 47-52.

ORTAS, I. Mycorrhiza in citrus: growth and nutrition. In: SRIVASTAVA, A. K. Advances in citrus nutrition. Amsterdam: Springer, 2012. p. 333-351.

PHILLIPS, J. M.; HAYMAN, D. S. Improved procedures for cleaning roots and staining parasitic and vesiculararbuscular mycorrhizal fungi for rapid assessment of infection. Transactions of the British Mycological Society, v. 55 , n. 1 , p. $158-161,1970$.

SILVEIRA, S. V. et al. Mentha piperita as a multiplying of arbuscular mycorrhizal fungi. Revista Brasileira de Plantas Medicinais, v. 8, n. 1, p. 91-97, 2006.

SMITH, S. E.; SMITH, F. A. Roles of arbuscular mycorrhizas in plant nutrition and growth: new paradigms from cellular to ecosystem scales. Annual Review of Plant Biology, v. 62, n. 1, p. 227-250, 2011.
SOUZA, E. L. de S.; SCHWARZ, S. F.; OLIVEIRA, R. P. Porta-enxertos para citros no Rio Grande do Sul. In: FUNDAÇÃO ESTADUAL DE PESQUISA AGROPECUÁRIA (Fepagro). Indicações técnicas para a citricultura no Rio Grande do Sul. Pelotas: Fepagro, 2010. p. 19-26.

SOUZA, P. V.; SCHÄFER, G. Produção de mudas de laranjeiras. In: KOLLER, O. C. (Org.). Citricultura: 1. Laranja: tecnologia de produção, pós-colheita, industrialização e comercialização. Porto Alegre: Cinco Continentes, 2006. p. 55-87.

WU, Q. S. et al. Root morphological modification of mycorrhizal citrus (Citrus tangerine) seedlings after application with exogenous polyamines. The Journal of Animal \& Plant Sciences, v. 21, n. 1, p. 20-25, 2011b.

WU, Q. S; ZOU, Y. N.; HEB, X. H. Differences of hyphaland soil phosphatase activities in drought-stress edmycorrhizal trifoliate orange (Poncirus trifoliata) seedlings. Scientia Horticulturae, v. 129, n. 1, p. 294298, 2011a.

ZAMBROSI, F. C. B. et al. Eficiência de absorção e utilização de fósforo em porta-enxertos cítricos. Revista Brasileira de Ciência do Solo, v. 36, n. 2, p. 485-496, 2012. 